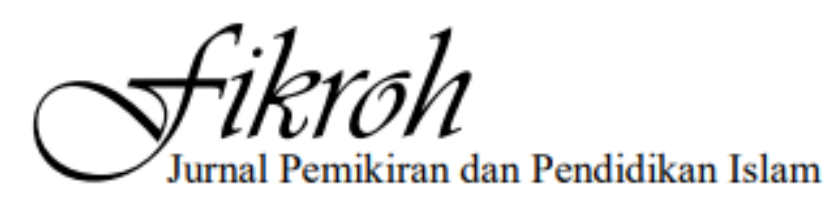

Fikroh : Jurnal Pemikiran dan Pendidikan Islam

Volume. 14, Number. 2, Juli 2021

p-ISSN : 2087-7501, e-ISSN : 2715-4459

HIm : 184-200

Journal Home Page : https://jurnal.stai-alazharmenganti.ac.id/index.php/fikroh

\title{
PENINGKATAN AKHLAK BERPAKAIAN DAN BERHIAS SISWI MELALUI PEMAHAMAN FIQIH WANITA DI MAN KOTA PASURUAN
}

\author{
Miftakhul Munir \\ Sekolah Tinggi Ilmu Tarbiyah Persatuan Guru Republik Indonesia Pasuruan Indonesia \\ Email: miftakhulm55@gmail.com \\ Suci Niswati \\ SDN Bangilan Kota Pasuruan \\ Email: suciniswati8@gmail.com
}

\begin{abstract}
Increasing the character of dress and decoration of students through the understanding of figh of women in MAN Pasuruan City, MAN Pasuruan City students use uniforms in an Islamic way, at least the hair and limbs are not visible apart from the hands and face. Meanwhile, the efforts of PAI teachers in improving the dress and decorating morals of students through the understanding of women's fiqh in Pasuruan City MAN, namely trying their best, especially female students always cover their genitals not only at school but outside school, they must always cover their genitals, if women have their genitals all over their faces and palms. . Then many of them have followed recommendations to cover their genitals, especially from religious teachers. Whereas the method used by Islamic Education teachers in improving the dress and decorating morals of students through the understanding of women's figh in MAN Pasuruan City is the most important method is the habituation method, so if you meet students there are things that are not good seen will be given directions, lecture methods and discussion, and methods of providing motivation.
\end{abstract}

Keywords: Drees and Make Up Morals, Understanding Of Women's Fiqh 


\begin{abstract}
Abstrak
Peningkatan akhlak berpakaian dan berhias siswi melalui pemahaman fiqih wanita di MAN Kota Pasuruan adalah siswi MAN Kota Pasuruan menggunakan seragam dengan cara yang islami, minimal tidak kelihatan rambut dan anggota tubuhnya yang selain tangan dan wajah. Sedangkan upaya guru PAI dalam meningkatkan akhlak berpakaian dan berhias siswi melalui pemahaman fiqih wanita di MAN Kota Pasuruan yakni berusaha semaksimal mungkin khususnya siswa perempuan selalu menutup aurat bukan hanya di sekolah tetapi di luar sekolah harus selalu menutup aurat, kalau perempuan auratnya seluruh muka dan telapak tangan. Kemudian mereka sudah banyak yang mengikuti anjuran-anjuran untuk menutup aurat khususnya dari guru agama. Sedangkan metode yang digunakan oleh guru PAI dalam dalam meningkatkan akhlak berpakaian dan berhias siswi melalui pemahaman fiqih wanita di MAN Kota Pasuruan adalah metode yang paling utama adalah metode pembiasaan, jadi kalau bertemu dengan siswa ada hal yang kurang baik dilihat akan diberikan arahan, metode ceramah dan diskusi, dan metode pemberian motivasi.
\end{abstract}

Kata kunci: Akblak Berpakaian dan Berbias, Pemahaman Fiqib Wanita

\title{
A. Pendahuluan
}

Pendidikan agama Islam, pengertian kata pendidikan, pada umumnya merujuk pada istilah at-tarbiyah, at-ta'dib dan at-ta'lim. Istilah yang selalu dipakai dalam pendidikan Islam yaitu istilah at-tarbiyah. ${ }^{1}$ Istilah at-tarbiyah berasal dari kata rabb, yang artinya tumbuh, memelihara, berkembang, mengatur, merawat, dan menjaga kelestarian atau keberadaannya. ${ }^{2}$ Dalam arti yang luas, arti dari pendidikan Islam yang ada di dalam istilah At-Tarbiyah dibagi menjadi empat komponen pendekatan, yakni: (1) merawat dan melindungi fitrah anak didik menjelang usia dewasa, (2) menumbuhkan segala kemampuan mendekati kesempurnaan, (3) mengarahkan seluruh fitrah menuju kesempurnaan, (4) mewujudkan pembelajaran secara bertingkat.

Pengertian pendidikan dapat dilihat dari istilah lain yang seakan searah dengan kata attarbiyah, yang antara lain dapat dipahami dengan merujuk firman Allah Swt. dalam QS. AlIsra’ [17]: 24 berikut:

${ }^{1}$ Ahmad Syalabi, Tarikh Al-Tarbiyah Al-Islamiyat, (Kairo: Al-Kasyraf, 1954), 25

2 Ibn Abdullah Muhammad bin Ahmad Al-Anshary Al-Qurtubiy, Tafsir Al-Qurtuby, Juz I, (Kairo: Dar Al-Sya'biy, 1998), 25 


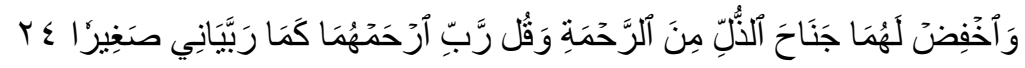

Artinya : "Dan rendabkanlah dirimu terbadap mereka berdua dengan penuh kesayangan dan ucapkanlab: "Wabai Tubanku, kasibilah mereka keduanya, sebagaimana mereka berdua telah mendidik aku waktu kecil". (QS. Al-Isra'[17]: 24)

Fahr Al-Razy, mengartikan istilah “rabbayan?" sebagai bentuk pembelajaran Islam arti luas. Istilah itu bukan hanya menunjukkan arti pembelajaran yang berupa perkataan (ranah kognitif), melainkan mencakup pembelajaran atas segi perilaku (ranah afektif). ${ }^{3}$ Demikian pula Sayyid Quthub menafsirkan istilah pembelajaran seperti cara perlindungan lahiriah anak didik dan menolongnya, menanamkan kemantapan perilaku moral sebagai gambaran budi pekerti yang baik atas pribadi anak didik. ${ }^{4}$

Dari pandangan diatas, memberikan pengertian bahwa istilah at-tarbiyah meliputi seluruh segi pembelajaran, yaitu segi kognitif (pengetahuan), afektif (sikap), dan psikomotorik (keterampilan). Baik yang mencakup segi jasmaniah, maupun rohaniah secara harmonis, sehingga akan terbina kemaslahatan umat manusia itu sendiri. Oleh karena itu, dalam pandangan An-Nahlawi, kata At-Tarbiyah, mengandung dua makna, yaitu metode perubahan sesuatu mencapai garis keutamaan (kematangan) juga dilaksanakan secara bertingkat. ${ }^{5}$ Dari penjelasan arti yang ditandai oleh kata at-tarbiyah, yakni pembelajaran yang dianjurkan harus berjalan secara terarah, bersistem, mempunyai tujuan yang hendak diperoleh, terdapat penyelanggara (guru), juga mempunyai teori-teori tertentu. Bila demikian, pesan yang dimuat dalam istilah at-tarbiyah, cukup cocok dipakai dalam menunjuk pada pengertian pendidikan Islam karena telah mencakup semua ranah kognitif, afektif dan psikomotorik.

Pendidikan Islam dikembangkan untuk memuliakan manusia atau memanusiakan manusia. Sudah seharusnya bagi orang yang berpendidikan artinya orang yang berilmu, yang mengerti dan memahami nilai-nilai kemanusiaan yang hakiki, menjadikan ilmu pengetahuan sebagai bekal untuk meningkatkan harkat dan martabat manusia. Harkat dan martabat manusia dibangun oleh keimanan dan keluhuran budi pekertinya. Ukuran budi pekerti yang

\footnotetext{
${ }^{3}$ Far Al-Razy, Tafsir Fabr Al-Razy, Juz XXI, (Teheran: Dar Al-Kutub Al-Islamiah, 1999), 27

${ }^{4}$ Sayyid Quthub, Tafsir Fi Drilal Al-Qur'an, Juz XV, (Beirut: Dar Al-Ahyat, 2000), 27

5 Abd. Rahman An-Nahlawi, Ushul At-Tarbiyah, Al-Islamiyah Wa Asalibuha Fi Al Bait, Wa Al-Madrasah Wa Al-Mujtama', (Damaskus: Dar Al-Fikr, 1998), hal. 28
} 
baik adalah yang serasi dengan tuntunan agama, peraturan yang berlaku, dan norma-norma dalam masyarakat. ${ }^{6}$

Masyarakat terbagi atas laki-laki maupun perempuan. Contoh pendidikan bagi perempuan ada bervariasi bentuknya, misalnya: hukum-hukum yang menjelaskan masalah thaharah, shalat, puasa, nikah, akhlak berpakaian maupun akhlak berhias yakni terdapat di dalam Fiqih Wanita. Maka dari itu, saat agama Islam hadir di dunia ini, Islam sudah menjunjung kedudukan wanita ke harkat yang makin mulia, membagikan keleluasan, harga diri dan hak individu serta merdeka. Allah sudah memberi wanita hak untuk menentukan baik dalam hal aqidah (keyakinan), perkawinan, dan seluruh segi aktivitas yang lain. Apalagi mereka diberi kebebasan untuk mempunyai kekayaan, melaksanakan negoisasi perdagangan, hadiah, warisan dan sebagainya. Islam betul-betul sudah melindungi hak-hak kelompok wanita. Islam meletakkan seorang wanita menjadi ibu, saudara wanita, istri dan anak, dan Islam sudah meletakkan mereka pada kedudukan yang utama. Islam melindungi kehidupan kelompok wanita atas melawan adat-istiadat memendam anak wanita hiduphidup laksana gambaran permusuhan rakyat sebelum adanya Islam kepada kelompok itu, berlangsung di zaman jahiliyah. Hal tersebut merupakan pengetahuan yang bermanfaat bagi manusia. Karena secara tidak langsung Islam telah mengajarkan kepada mereka bahwa tidak ada perbedaan antara laki-laki maupun perempuan. ${ }^{7}$

Dari penjelasan bahwa Islam tidak membedakan kaum laki-laki dan perempuan, maka terdapat hukum yang membahas persoalan wanita yakni dinamakan Fiqih Wanita. Fiqih wanita adalah ilmu fiqih yang membahas tentang masalah wanita, seperti: haid, nifas, istihadhah termasuk juga ibadah sholat yang merupakan kewajiban bagi setiap muslimah. ${ }^{8}$ Di dalam fiqih wanita juga membahas akhlak berpakaian maupun akhlak berhias bagi wanita muslimah. Berpakaian seorang wanita muslimah tidak lain untuk menutupi bagianbagian tubuh dengan karakteristik pakaian tersebut menutupi semua anggota badan melainkan muka dan telapak tangan karena setiap lekuk anggota tubuh perempuan adalah aurat, pakaian tersebut tidak ketat dan tidak menonjolkan bentuk tubuh, pakaian wanita

${ }^{6}$ Hasan Basri dan Beni Ahmad Saebani, Ilmu Pendidikan Islam (Jilid II), (Bandung: CV. Pustaka Setia, 2010), hal. 29

${ }^{7}$ Mutawalli As-Sya'rawi, Fikih Perempuan (Muslimab), (Jakarta: AMZAH, 2003), hal. 109 36

${ }^{8}$ Ummu Harits dan Irfan Supandi, Berburu Pahala Ketika Haid, (Surakarta: Ziyad Visi Media, 2007), hal. 
muslimah tidak boleh menyerupai pakaian laki-laki atau sebaliknya dan pakaian wanita muslimah tidak boleh transparan. Syarat pakaian muslimah yakni ada 8, diantaranya:

1. Menutupi seluruh anggota badannya melainkan muka dan telapak tangan.

2. Jangan sampai pakaian tersebut menjadi perhiasan dirinya.

3. Hendaknya menggunakan pakaian yang tebal sehingga tidak bisa tembus pandang.

4. Hendaknya pakaian tersebut longgar sehingga tidak menampakkan bagian dari lekuk tubuhnya.

5. Hendaknya pakaian tersebut jangan beraroma (berparfum) wangi.

6. Hendaknya pakaiannya jangan menyerupai pakaian lelaki.

7. Hendaknya pakaian tersebut tidak menyerupai pakaian orang kafir, karena syariat memberlakukan bahwa tidak boleh bagi seorang muslim baik laki-laki ataupun perempuan untuk menyerupai orang kafir baik itu dalam ibadahnya, kebiasaannya ataupun pakaian yang secara khusus bagi mereka.

8. Jangan sampai busana yang dikenakannya dijadikan sebagai alat untuk mencari popularitas.

Sedangkan akhlak berpakaian menurut syari'at Islam diantaranya: jangan berlebihlebihan dalam berpakaian, jika mau berpakaian berdo'alah terlebih dahulu, memulai dengan bagian kanan apabila hendak memakai pakaian, jangan pernah memakai pakaian yang terdapat gambar salibnya, jangan pernah memakai pakaian yang terbuat dari kulit binatang buas, dan jangan berjalan dengan menggunakan satu sandal.

Adapun fungsi pakaian salah satunya sebagai perhiasan. Perhiasan adalah sesuatu yang dipakai untuk memperelok serta memperindah. Berhias agar tampil indah, dan bersih merupakan nilai-nilai yang ditanamkan dalam Islam. Berikut ini akhlak berhias, diantaranya: memakai perhiasan dengan tidak berlebihan, bagi wanita yang sedang berkabung tidak boleh memakai perhiasan, jangan membuat tato, tidak diperbolehkan memakai perhiasan yang dilarang seperti parfum yang bercampur alkohol, tidak diperbolehkan berhias diri dengan mengubah wujud aslinya seperti mengeriting rambut dan muncukur alis mata secara permanen, dianjurkan untuk memotong kuku dan menyisir rambut. Diantara akhlak berhias yang disebutkan diatas, Islam bahkan mengajarkan agar wanita tidak berhias kecuali untuk suaminya. Di sisi lain, kebiasaan berhias tampaknya amat sejalan dengan fitrah insani, 
terutama kaum wanitanya. Sehingga saat ini ada beragam akhlak berhias, bentuk dandanan dan semisalnya tampil di berbagai tempat.

Tujuan dari fiqih wanita pada hakikatnya sama dengan tujuan fiqih itu sendiri, menurut Abdul Wahab Kholaf, tujuan ilmu fiqih yaitu menerapkan syara' pada semua ucapan serta perbuatan manusia. Sehingga ilmu fiqih menjadi rujukan oleh seorang hakim dalam mengambil keputusannya, seorang mufti didalam fatwanya serta seorang mukallaf untuk memahami hukum syara' atas perbuatan serta ucapannya. Ini adalah undang-undang yang ada dalam manusia. Dia tidak mempunyai tujuan kecuali melaksanakan materi serta hukumnya pada perbuatan dan ucapan manusia, juga mengenalkan kepada orang mukallaf mengenai hal-hal yang wajib serta yang haram baginya.

Sedangkan menurut buku pembelajaran PAI menjelaskan tujuan pembelajaran fiqih adalah untuk menanamkan serta mengembangkan keimanan, melalui pemupukan serta pemberian ilmu pengetahuan, penghayatan pengalaman serta pengalaman siswa-siswi dalam aspek hukum baik yang berupa ajaran ibadah maupun mu'amalah sehingga mencetak manusia muslim yang terus berkembang dalam hal keimanan, ketaqwaannya kepada Allah Swt. serta berakhlakul karimah dalam kehidupan individu, bermasyarakat, berbangsa serta bernegara, dan dapat meneruskan ke tingkat pendidikan yang makin tinggi. Akan tetapi dalam kaitannya dengan fiqih wanita, maka tujuan dari pembelajaran fiqih berbeda dengan tujuan pembelajaran fiqih wanita. Adapun tujuan dari pembelajaran fiqih wanita adalah lebih spesifik dalam penerapan hukum-hukum syara' yang berkaitan dengan masalahmasalah pembawaan pada kaum perempuan. Seperti hukum mengenai seorang perempuan yang haid maka seorang perempuan harus mengetahui apa yang dapat dikerjakan dan yang dilarang ketika dia sedang haid. ${ }^{?}$

Fenomena yang muncul dari kebiasaan berpakaian dan berhias terutama bagi para siswi saat ini yaitu lebih memilih berpakaian ketat sehingga membentuk lekuk tubuhnya, terbuka auratnya dan tidak mengulurkan jilbabnya. Mereka lebih memilih mengikuti trend fashion sehingga tidak memperhatikan koridor syar'i. Maka dari itu, melalui pemahaman fiqih wanita tersebut menjadi bukti akan tingginya perhatian Islam terhadap pembinaan dan pendidikan wanita, dan diharapkan para siswi lebih memperhatikan lagi bagaimana akhlak

${ }^{9}$ Kamil Muhammad, Fikih Wanita, (Jakarta Timur: Pustaka Al-Kautsar, 1998) hal. 8 
mereka berpakaian yang sinkron sama keyakinan Islam dan berhias dengan tidak berlebihan, karena tujuan mereka sebenarnya yakni menuntut ilmu agar bermanfaat di zaman yang akan tiba. Tingginya perhatian Islam terhadap hukum wanita seharusnya menyadarkan para siswi akan pentingnya meningkatkan pendidikan dan pembinaan terhadap siswa.

\section{B. Metode Penelitian}

Penelitian ini merupakan penelitian kualitatif dengan jenis studi kasus yaitu sebuah cara penelitian menggunakan pendekatan studi kasus, peneliti akan "menghabiskan waktu" dalam menggambarkan konteks, seorang peneliti mengeksplorasi suatu fenomena tertentu (kasus) dalam suatu waktu dan kegiatan (program, event, proses, institusi atau kelompok sosial) dan mengumpulkan informasi secara terperinci dan mendalam dengan menggunakan berbagai proses pengumpulan data selama periode tertentu. ${ }^{10}$

Jenis data ini digunakan pada penelitian kualitatif, penelitian deskriptif, penelitian historis, dan penelitian filosofi. Data kualitatif ditunjukkan dalam susunan kalimat dan uraian-uraian, bahkan dapat berbentuk cerita pendek. Data kualitatif bersifat subjektif, karena peneliti menggunakan data kualitatif harus berupaya untuk menjauhi sikap subjektif yang dapat mengaburkan objektivitas data penelitian. ${ }^{11}$ Sumber data merupakan tempat pengambilan data atau subjek dari mana data diperoleh. ${ }^{12}$ Dalam penelitian ini sumber data yang diperlukan adalah sumber data yang relevan dengan pembahasan penelitian. Adapun berikut sumber data dapat dibagi menjadi dua, yaitu:

1. Data Primer, yakni data yang didapat langsung dari sumbernya yang diamati dan dicatat untuk pertama kalinya. Adapun data primer dari penelitian ini adalah keseluruhan data yang didapat dengan cara wawancara, observasi, dan dokumentasi di MAN Kota Pasuruan.

2. Data Sekunder, yakni data yang tidak langsung memberikan data kepada pengumpul data (peneliti). Dengan kata lain, data sekunder adalah data yang diperoleh peneliti dari

${ }^{10}$ John W Creswell, Qualitative Inquiry and Research Design Choosing Among Five Tradition, (London: SAGE Publication, 1998), hal. 372-373

${ }^{11}$ Burhan Bungin, Penelitian Kualitatif, (Jakarta: Kencana Prenada Media Group, 2001), hal. 103

12 Suharsimi Arikunto, Prosedur Penelitian: Suatu Pendekatan Praktik, (Jakarta: Renata Cipta, 2002), hal. 107 
sumber buku, majalah, koran, dokumen pribadi, dokumen resmi sekolah dan lain sebagainya. Data sekunder ini digunakan sebagai data pendukung dari data primer. Data ini didapat atau diperoleh dari dokumen-dokumen MAN Kota Pasuruan. Data sekunder yang diperoleh meliputi: lokasi MAN Kota Pasuruan, sejarah berdirinya MAN Kota Pasuruan, struktur organisasi MAN Kota Pasuruan, dan beberapa dokumen yang relevan dengan kegiatan madrasah.

Penelitian Kualitatif ini menggunakan teknik pengumpulan data dengan cara interview, dokumentasi dan wawancara. Analisis Data yang digunakan dengan menggunakan Reduksi data, Data Display/Penyajian Data, Data Verifikasi/Penarikan Kesimpulan. Sedangkan Pengecekan Keabsahan Data meliputi Perpanjangan Pengamatan, Meningkatkan ketekunan, Triangulasi. Tahapan-tahapan penelitian meliputi Tahap Pra Lapangan, Tahap Pekerjaan Lapangan, tahap analisis data.

\section{Hasil dan Pembahasan}

\section{Akhlak Berpakaian dan Berhias Siswi di MAN Kota Pasuruan}

Adapun akhlak berpakaian dan berhias yang diterapkan di MAN Kota Pasuruan seperti yang diungkapkan oleh Ita Miftakhul Jannah, M. Pd selaku guru fiqih dan akidah akhlak di Madrasah Aliyah Negeri Kota Pasuruan, beliau mengatakan:

"Sebenarnya sudah ada ketentuan ketika siswa itu mau daftar disini sudah ada gambar pola baju yang diberikan oleh sekolah. kemudian terkait dengan berbias itu anak-anak yang melebibi batas kewajaran seperti ber make up atau menggunakan aksesoris yang berlebiban kita berikan arahan. Kalau disini tidak banyak yang memakai make up, tapi mungkin ada kasus-kasus seperti itu. biasanya kalau gurunya tidak bisa menangani siswa itu maka bekerjasama dengan wali kelas, kalau masih tidak dapat ditangani maka langsung dibawa ke BK. jadi aturan-aturan yang terkait dengan berpakaian dan berbias ini bisa ditangani sampai ke guru BK perempuan". ${ }^{13}$

Hal yang sama juga diungkapkan oleh Muhamad Hayat, S.Ag M.Pd.I selaku guru akidah akhlak di MAN Kota Pasuruan, beliau mengatakan: Pasuruan.

${ }^{13}$ Wawancara dengan Ita Miftakhul Jannah, M. Pd selaku guru fiqih dan akidah akhlak di MAN Kota 
"Kalau di MAN itu menggunakan cara yang islami, minimal tidak. kelihatan rambut dan anggota tububnya yang selain tangan dan wajah". ${ }^{14}$

Dalam hal ini penulis dapat menganalisis bahwasannya akhlak berpakaian dan berhias yang diterapkan di MAN Kota Pasuruan adalah sebagai berikut:

a. Ketika siswa-siswi daftar sekolah di MAN Kota Pasuruan, mereka diberikan gambar pola baju yang harus mereka gunakan di sekolah.

b. Mengenai berhias anak-anak yang melebihi batas kewajaran seperti ber make up atau menggunakan aksesoris yang berlebihan akan diberikan arahan.

c. Menggunakan cara yang islami, minimal tidak kelihatan rambut dan anggota tubuhnya yang selain tangan dan wajah.

Sedangkan pembelajaran tentang akhlak berpakaian dan berhias di MAN Kota Pasuruan seperti yang diungkapkan oleh Ita Miftakhul Jannah, M.Pd selaku guru fiqih dan akidah akhlak di MAN Kota Pasuruan, beliau mengatakan:

"Kelas X Agama sebenarnya sudah ada pembelajaran akblak berpakaian dan berbias di semester 2, sampai bagaimana cara memakai baju dan do'a memakai baju kemudian bagaimana menutupi aurat dan berbias (larangan menyambung rambut dan memotong kuku) itu juga diperbatikan". ${ }^{15}$

Dalam kesempatan lain, penulis juga melakukan wawancara kepada Muhamad Hayat, S.Ag,.M.Pd.I selaku guru akidah akhlak di MAN Kota Pasuruan, beliau mengatakan:

"Sudah ada, di kelas XII Agama semester 2 materi akblak. dan kalau di kelas XI Agama itu di semester 1". ${ }^{16}$

Dalam hal ini penulis dapat menganalisis bahwasannya pembelajaran tentang akhlak berpakaian dan berhias di MAN Kota Pasuruan sudah ada di kelas X, XI dan XII jurusan Agama. Pasuruan.

14 Wawancara dengan Muhamad Hayat, S.Ag, M.Pd.I selaku guru akidah akhlak di MAN Kota Pasuruan.

15 Wawancara dengan Ita Miftakhul Jannah, M. Pd selaku guru fiqih dan akidah akhlak di MAN Kota Pasuruan.

16 Wawancara dengan Muhamad Hayat, S.Ag M.Pd.I selaku guru akidah akhlak di MAN Kota 
Akhlak menurut Prof. KH. Farid Ma'ruf adalah kehendak jiwa manusia yang menimbulkan perbuatan dengan mudah karena kebiasaan, tanpa memerlukan pertimbangan pikiran terlebih dahulu. ${ }^{17}$

Menurut tuntunan agama Islam, berpakaian yakni memakai pakaian untuk menutupi aurat, serta sekaligus perhiasan untuk memperindah tubuh seseorang. Sebagaimana yang sudah dijelaskan oleh Allah Swt. dalam firman-Nya QS. Al-A'raf [7]: 26 berikut:

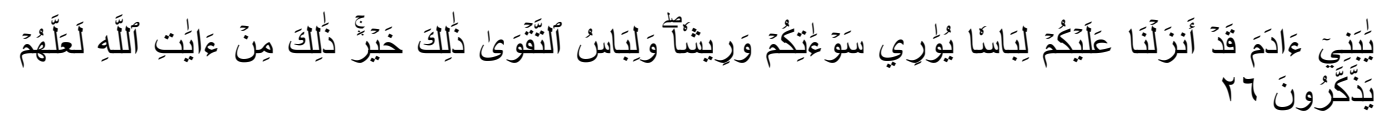

Artinya: "Wahai anak Adam! Susunggubnya Kami telah menyiapkan pakaian untuk menutupi auratmu dan untuk perbiasan bagaimu tetap takwa itulah yang lebih baik. Begitulah sebagian tanda-tanda kekuasaan Allah, mudah-mudahan mereka selalui ingat'. (QS. Al-A'raf [7]: 26)

Ayat tersebut memberikan contoh tata cara berpakaian sebagaimana yang dituntut untuk sifat taqwa, yaitu untuk menutup aurat serta berpakaian yang rapi, sehingga akan terlihat simpati, berwibawa serta anggun dipandang, bukan menggiurkan.

Seseorang perempuan dinilai berpakaian yang baik serta serasi agar mereka senantiasa menggunakan pakaian yang pantas dengan usianya serta karakternya masing-masing. ${ }^{18}$

Pegangan utama yang harus diperhatikan ketika berpakaian, yaitu tidak berlebihan serta lebih baik berpakaian yang sederhana dan menutupi auratnya.

Menurut tuntunan agama Islam, aurat perempuan muslimah adalah seluruh anggota tubuhnya, kecuali wajah serta telapak tangan, maka wajib seorang wanita Islam menjaga beberapa bagian tubuhnya serta menutupi dadanya dengan memakai kerudung. Sedangkan Ilmu Fiqih menegaskan bahwa aurat laki-laki yaitu diantara pusar sampai lutut sehingga pakaian pria tidak sama dengan pakaian wanita dalam menutupi auratnya.

${ }^{17}$ Mustofa, Akblak Tasawuf. (Bandung: Pustaka Setia, 2014), hal. 14

${ }^{18}$ Labib dan Muflihah, Fiqib Wanita Muslimah. (Banyuwangi: Cahaya Agenc, 2010), hal. 284 
Akhlak berpakaian adalah suatu bentuk sikap dan perilaku dalam akhlak berpakaian yang ditampilkan oleh seseorang dalam bentuk perbuatan dan menjadi cermin kepribadian yang dimiliki dalam kehidupan sehari-hari. ${ }^{19}$

Maka peneliti dapat menyimpulkan bahwa akhlak berpakaian di MAN Kota Pasuruan adalah sebagai beeikut:

a. Ketika siswa-siswi daftar sekolah di MAN Kota Pasuruan, mereka diberikan gambar pola baju yang harus mereka gunakan di sekolah.

b. Mengenai berhias anak-anak yang melebihi batas kewajaran seperti ber make up atau menggunakan aksesoris yang berlebihan akan diberikan arahan.

c. Menggunakan cara yang islami, minimal tidak kelihatan rambut dan anggota tubuhnya yang selain tangan dan wajah.

Sedangkan pembelajaran tentang akhlak berpakaian dan berhias di MAN

Kota Pasuruan sudah ada di kelas X, XI dan XII di mata pelajaran bidang studi PAI.

\section{Pemahaman Fiqih Wanita di MAN Kota Pasuruan}

Lembaga pendidikan yang bersifat madrasah, sudah ada pembelajaran mengenai pemahaman tentang fiqih wanita dan hal-hal yang dibahas didalamnya. Berdasarkan pemerolehan data yang kami lakukan dengan melakukan wawancara kepada Ita Miftakhul Jannah, M.Pd selaku guru fiqih dan akidah akhlak di MAN Kota Pasuruan mengenai pemahaman tentang fiqih wanita yang ada di MAN Kota Pasuruan dan hal-hal yang dibahas di dalam fiqih wanitaadalah sebagai berikut:

"Di MAN Pasuruan sekarang sistemnya sudah SKS, jadi pemahaman anak itu sudah cepat. Terkait dengan pembelajaran fiqib wanita sangat luas, kalau pembelajaran fiqibnya sendiri di materi fiqih wanita kelas $X$ itu belum disampaikan, karena kita mengikuti kurikulum dari Kemenag. Kalau pada bab thoharoh adanya di MI dan MTs, kalau di MA sudah lebih dari itu, hanya saja kalau pembahasan fiqib wanita itu sendiri sangat luas, bisa terkait dengan pernikahan dan cara berbias dan seterusnya. Kalau kita bicara adab berpakaian dan berbias itu dibahas secara spesifik di materi akblak. Kalau di MAN ini fiqibnya ada 2 yang harus kita ketahui, yang pertama dijelaskan dipelajaran tetapi tidak spesifik dan yang kedua diterapkan di keputrian, secara tidak langsung bisa menjadi kebiasaan yang diterapkean dalam kehidupan sehari-hari siswi. Jika dalam keputrian itu materinya ada dan disampaikan oleh guru tertentu, dan juga ada kitabnya sendiri, baik. tentang fiqih wanita yang membahas tentang thoharoh dan lain-lain. Kemudian tentang

19 Zakiah Darajat, Metodik Khusus Pengajaran Agama Islam. (Jakarta: Bumi Aksara, 2011), hal. 68. 
kebiasaan atau adab berpakaian dan berbias yang dilakukan di MAN ini seperti dalam berpakaian, jilbabnya kelibatan rambutnya kita peringatan disitu atau jilbabnya tidak. menutupi dada kita nasehati dulu kemudian ditegur. atau dalam keseharian babkan diterapkan oleh guru PAI di kelas, katakanlah anak-anak tidak memakai inner/iket kerudung sehingga kelihatan rambutnya, awalnya kita berikan peringatan dan ditegur. Biasanya saya di kelas membuat kesepakatan dengan siswi, terutama masalah jilbab karena sudah aturan disini tidak boleh kelihatan rambutnya. Kesepakatan saya biasanya kalau anak-anak tetap melanggar boleb tidak mengikuti pelajaran saya, itu adalab bukuman terakbir ketika anak tidak mau mengikuti aturan-aturan yang ada di sekolah. Sebenarnya ini bukan hanya aturan tetapi bagaimana anak ini mengaplikasikan adabadab bagaimana yang sesuai dengan syari'at" ${ }^{20}$

Dalam hal ini penulis dapat menganalisis bahwasannya pemahaman fiqih wanita yang ada di MAN Kota Pasuruan sangat luas, seperti contohnya: menjelaskan tentang haid, pernikahan dan cara berhias maupun berpakaian. Hanya saja mengenai adab berpakaian dan berhias itu dibahas secara spesifik di materi akhlak. Kalau di MAN fiqihnya ada 2 yang harus kita ketahui, yang pertama dijelaskan dipelajaran tetapi tidak spesifik dan yang kedua diterapkan di keputrian, secara tidak langsung bisa menjadi kebiasaan yang diterapkan dalam kehidupan sehari-hari siswi. Jika dalam keputrian materinya ada dan disampaikan oleh guru tertentu, dan juga ada kitabnya sendiri, baik tentang fiqih wanita yang membahas tentang thoharoh dan lain-lain.

Di dalam Taksonomi Bloom, dijelaskan bahwa pemahaman yakni kemauan mengetahui sederajat makin tinggi dari pengetahuan. Namun, bukan bermakna bahwa pengetahuan tidak diragukan karena akan bisa mengetahui, sebelumnya harus memahami ataupun mengenal. ${ }^{21}$

Sedangkan arti fiqih wanita adalah pengetahuan atau pemahaman tentang hukum-hukum Islam yang membahas sesuatu yang terkait dengan masalah kewanitaan yang kaitannya dengan tindakan atau perbuatan secara praktis yang disertai dengan dalil-dalil yang terperinci.

Adapun dasar Fiqih Wanita ada dua, yaitu: Pasuruan.

${ }^{20}$ Wawancara dengan Ita Miftakhul Jannah, M. Pd selaku guru fiqih dan akidah akhlak di MAN Kota

21 Mushlihin, 2013, Pengertian Pemahaman Dalam Pembelajaran, dalam https://www.referensimakalah.com/2013/05/pengertian-pemahaman-dalam-pembelajaran.html, diakses pada tanggal 10 April 2020, pukul 09.03 WIB. 
a. Al-Qur'an

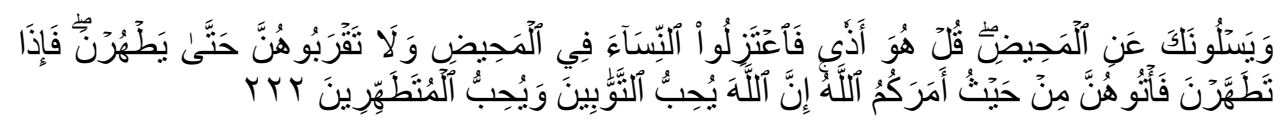

Artinya: "Mereka bertanya kepadamu tentang haidh. Katakanlab: "Haidh itu adalah suatu kotoran". Oleh sebab itu bendaklah kamu menjaubkan diri dari wanita di waktu haidh; dan janganlah kamu mendekati mereka, sebelum mereka suci. Apabila mereka telah suci, maka campurilah mereka itu di tempat yang diperintabkan Allah kepadamu. Sesunggubnya Allah menyukai orang-orang yang bertaubat dan menyukai orang-orang yang mensucikan diri”. (QS. Al-Baqarah [2]: 222)

Landasan mengapa memilih dalil ayat di atas adalah dikarenakan asbabun nuzul dari ayat tersebut karena adanya perbedaan pendapat yang sangat mencolok dari dua orang sahabat Nabi yang bertanya mengenai apa yang seharusnya dilakukan terhadap perempuan yang haid, sebagaimana dijelaskan bahwa pada zaman Arab dahulu haid dianggap sebagai suatu yang menjijikkan, sehingga pada saat itu dalam budaya agama Yahudi perempuan yang haid di usir dari rumah, tidak boleh tinggal dan makan di dalam rumah. Sementara para penganut agama Nasrani sama sekali tidak membedakan antara perempuan yang haid dan tidak, mereka tetap melakukan hubungan suami-istri dengan perempuan yang haid. ${ }^{22}$

b. Al-Hadits

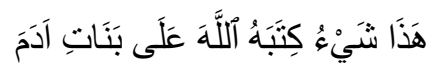

Artinya: "Ini (baidh) merupakan sesuatu yang digariskan Allab kepada anak cucu (wanita) adam. (HR. Bukhori dan Imam Muslim).

Adapun ruang lingkup pembahasan Fiqih Wanita yakni:

Menurut Yusuf Qardhawi keistimewaan pembahasan mengenai wanita dalam fiqih selanjutnya menciptakan cabang fiqih tersendiri, yakni fiqhunnisa' ataupun diartikan dengan fiqih wanita. Biasanya fiqih wanita menjelaskan tentang haid, nifas, isthikhadhoh, kewajiban menutup aurat, kesesuaian, warisan dan sejenisnya disertai dengan ancaman-ancaman yang sangat menakutkan bagi yang tidak melaksanakannya. Penyajian materi tentang wanita, yang utama terhadap hal-hal

${ }^{22}$ Moenawar Khalil, Nilai Wanita. (Solo: CV. Ramadhani, 1989), hal. 12 
yang dibedakan hukumnya dengan laki-laki dilengkapi dengan penjelasan bahwa pembedaan itu tidak menunjukkan ketidak adilan Islam, tetapi justru banyak hikmahnya dikarenakan secara kodrat perempuan memiliki keterbatasan akal, tenaga, dan pengalaman. Menurut Syaikh kamil Muhammad menyebutkan bahwa berdasarkan Al-Qur'an dan Hadits hukum-hukum yang berkenaan dengan wanita antara lain: Thaharah, Shalat, Puasa, Nikah, Hidup Bertetangga, dan Jual Beli. ${ }^{23}$

Pengetahuan tentang Fiqih Wanita menjadi acuan bagi seorang remaja perempuan dalam kehidupan sehari-hari. Bagaimana perempuan bersuci setelah haid, bagaimana tata cara perempuan melaksanakan shalat, bagaimana perempuan berpakaian dan berhias, dan bagaimana perempuan bersikap dalam kesehariannya harus bisa dipahami dan dilaksanakan dengan baik.

Menurut Nashiruddin dalam Zulfinatun Ni'mah pembahasan fiqih wanita atau fiqih perempuan biasanya mengenai thaharah (bersuci), darah haid, kehamilan, melahirkan, shalat, waris, nikah, mu'amalah, jinayah, tidak luput membahas perempuan secara khusus.

Dari pendapat di atas, dapat disimpulkan ruang lingkup pembelajaran fiqih wanita ini tentang thaharah, shalat, puasa, nikah, hidup bertetangga, jual beli, haid, nifas, istikhadhoh, kewajiban menutup aurat, kesaksian, warisan dan sejenisnya disertai dengan ancaman-ancaman yang sangat menakutkan bagi yang tidak melaksanakannya. Serta tentang permasalahan-permasalahan yang berkaitan tentang wanita.

Sedangkan tujuan dari fiqih wanita pada hakikatnya sama dengan tujuan fiqih itu sendiri, menurut Abdul Wahab Kholaf, tujuan ilmu fiqih yaitu menerapkan syara' pada semua ucapan serta perbuatan manusia. Sehingga ilmu fiqih menjadi rujukan oleh seorang hakim dalam mengambil keputusannya, seorang mufti di dalam fatwanya serta seorang mukallaf untuk memahami hukum syara' atas perbuatan serta ucapannya. Ini adalah undang-undang yang ada dalam manusia. Dia tidak mempunyai tujuan kecuali melaksanakan materi serta hukumnya pada

${ }^{23}$ Kamil Muhammad, Fikih Wanita. (Jakarta Timur: Pustaka Al-Kautsar, 1998), hal. 8 
perbuatan dan ucapan manusia, juga mengenalkan kepada orang mukallaf mengenai hal-hal yang wajib serta yang haram baginya.

Sedangkan menurut buku pembelajaran PAI menjelaskan tujuan pembelajaran fiqih adalah untuk menanamkan serta mengembangkan keimanan, melalui pemupukan serta pemberian ilmu pengetahuan, penghayatan pengalaman serta pengalaman siswa-siswi dalam aspek hukum baik yang berupa ajaran ibadah maupun mu'amalah sehingga mencetak manusia muslim yang terus berkembang dalam hal keimanan, ketaqwaannya kepada Allah Swt. serta berakhlakul karimah dalam kehidupan individu, bermasyarakat, berbangsa serta bernegara, dan dapat meneruskan ke tingkat pendidikan yang makin tinggi.

Akan tetapi dalam kaitannya dengan fiqih wanita, maka tujuan dari pembelajaran fiqih berbeda dengan tujuan pembelajaran fiqih wanita. Adapun tujuan dari pembelajaran fiqih wanita adalah lebih spesifik dalam penerapan hukumhukum syara' yang berkaitan dengan masalah-masalah pembawaan pada kaum perempuan. Seperti hukum mengenai seorang perempuan yang haid maka seorang perempuan harus mengetahui apa yang dapat dikerjakan dan yang dilarang ketika dia sedang haid. ${ }^{24}$

Jadi, pemahaman fiqih wanita siswi di MAN Kota Pasuruan adalah fiqihnya dibagi menjadi dua, yang pertama dijelaskan dipelajaran tetapi tidak spesifik dan yang kedua diterapkan di keputrian, secara tidak langsung bisa menjadi kebiasaan yang diterapkan dalam kehidupan sehari-hari siswi. Jika dalam keputrian itu materinya ada dan disampaikan oleh guru tertentu, dan juga ada kitabnya sendiri, baik tentang fiqih wanita yang membahas tentang thoharoh dan lain-lain.

\section{Simpulan}

Akhlak berpakaian dan berhias yang diterapkan di MAN Kota Pasuruan adalah Ketika siswa-siswi daftar sekolah di MAN Kota Pasuruan, mereka diberikan gambar pola baju yang harus mereka gunakan di sekolah, Mengenai berhias anak-anak yang melebihi batas kewajaran seperti ber make up atau menggunakan aksesoris yang

${ }^{24}$ Kamil Muhammad, Fikih Wanita, hal. 8 
berlebihan akan diberikan arahan, Menggunakan cara yang islami, minimal tidak kelihatan rambut dan anggota tubuhnya yang selain tangan dan wajah. Akhlak dalam menggunakan pakaian yang sesuai dalam syari'at Islam antara lain: Jangan berlebihlebihan dalam berpakaian, Jika kamu memakai pakaian baru maka berdo'alah, Mulailah dengan bagian kanan apabila hendak memakai pakaian, Jangan pernah memakai pakaian yang terdapat gambar salibnya, Jangan pernah memakai pakaian yang terbuat dari kulit binatang yang buas.

Pemahaman fiqih wanita yang ada di MAN Kota Pasuruan sangat luas, seperti contohnya: menjelaskan tentang haid, pernikahan dan cara berhias maupun berpakaian. Hanya saja mengenai adab berpakaian dan berhias itu dibahas secara spesifik di materi akhlak. Kalau di MAN fiqihnya ada 2 yang harus kita ketahui, yang pertama dijelaskan dipelajaran tetapi tidak spesifik dan yang kedua diterapkan di keputrian, secara tidak langsung bisa menjadi kebiasaan yang diterapkan dalam kehidupan sehari-hari siswi. Jika dalam keputrian materinya ada dan disampaikan oleh guru tertentu, dan juga ada kitabnya sendiri, baik tentang fiqih wanita yang membahas tentang thoharoh dan lainlain.

\section{E. Daftar Pustaka}

Departemen Agama RI. Al-Qur'an dan Terjemahnya. Bandung: Sygma Examedia Arkanleema, 2009.

Ali, Atabik dan Ahmad Zuhdi Muhdlor. Kamus Kontemporer Arab-Indonesia, Krapyak: Multi Karya Grafika, 2001.

Al-Jarim, Ali dan Musthafa Amin. Al- Balaghah Al-Wadlihah, Beirut: Muassasah al-Kutub ats-Tsaqafiyyah, 2008.

Al-Wa'ily, Sa'ad Abdul Karim Abbas. Thara'iq Tadris al-Adab wa al-Balaghah wa at-Ta'bir Baina at-Tandhir wa at-Tathbiq. Kairo: Dar asy-Syuruq, 2004.

Ash-Sha'idy, Abdul Mu'tal. Bughyatul Idlah li Talkhish al-Miftah fi Ulumi al-Balghah. Kairo: Makatabah al-Adab, 2009.

Astiti, Kadek Ayu. Evaluasi Pembelajaran. Yogyakarta: Andi, 2017.

Cikawati. Sastra Indonesia Untuk Siswa Madrasah Aliyah (MA). Yogyakarta: Deepublish, 2020.

Farhan, Ahmad. Living Al-Qur'an Sebagai Metode Alternatif dalam Studi Islam. El-Afkar. Vol. 6. No. II. (Juli-Desember 2017): 87-96. 
Fayud, Basyuni Abdul Fattah. Ilmul Badi' Dirasah Tarikhiyah wa Fanniyah li Ushulil Balaghah wa Masa'ilil Badi'. Kairo: Al-Mukhtar, 2011.

Fayud, Basyuni Abdul Fattah. Ilmul Ma'any (Dirasah Balaghiyah wa Naqdiyyah Limasail aMa'ani). Kairo: Al-Mukhtar, 2011.

Hafidz, Muhammad. Memahami Balaghah Dengan Mudah. Ta'limuna, Vol.7, No. 2 (2018): 129-145.

Hasan, Ali Muhammad. Asrarul Bayan. Kairo: Ummul Qura', 2006.

Ibrahim, Mustafa Abdur Rahman. An-Naqdu al-'Araby al-Qadim Indal 'Arab. Kairo: Percetakan Makkah, 1998.

Ibnu Hisyam, Jamaludin Abdullah. Audlahul masalik ila alfiyah ibni Malik. Beirut: Darel Fikr, 2007.

Izzan, Ahmad. Metodologi Pembelajaran Bahasa Arab. Bandung: Humaniora, 2015.

Ma'zumi, Syihabudin, dan Najmudin.). Pendidikan Dalam Perspektif Al-Qur'an Dan AlSunnah: Kajian Atas Istilah Tarbiyah, Taklim, Tadris, Ta'dib Dan Tazkiyah, TARBAWY: Indonesian Journal of Islamic Education, Vol. 6 No. 2. (2019): 194-209.

Murdiono. Al-Qur'an Sebagai Media Pembelajaran Ilmu Bayan. Malang: UMM Press, 2020.

Mushodiq, Muhamad Agus. Majaz Al-Quran Pemicu Lahirnya Ilmu Balaghah (Telaah Pemikiran 'Ali 'Asyri Zāid). An-Nabighoh, Vol. 20, No. 01. (2018): 45-62.

Nashif, Hafni, Muhammad Diyab, Mustafa Thamum, Muhammad Afandi Umar, dan Sultan Muhammad. Qawa'idul Lughah al-"arabiyyah li Talamidz al-Madaris ats-Tsanawiyyah. Surabaya: Al-Miftah, 2007.

Nurbayan, Yayan. Pengembangan Materi Ajar Balaghah Berbasis Pendekatan Kontrastif. Bahasa dan Seni. Tahun 38, No.1. (2010): 107-116.

Nurgiyantoro, Burhan. Stilistika. Yogyakarta: Gadjah Mada University Press, 2018.

Wicaksono, Andri. Pengkajian Prosa Fiksi (Ed. 1).Yogyakarta: Garudhawaca, 2004.

Prastowo, Andi. Menyusun Rencana Pelaksanaan Pembelajaran (RPP) Tematik Terpadu Implementasi Kurikulum 2013 untuk SD/MI. Jakarta: Kencana, 2015.

Prastowo, Andi. Analisis Pembelajaran Tematk Terpadu. Jakarta: Kencana, 2019.

Rusman. Belajar dan Pembelajaran Berorientasi Standar Proses Pendidikan. Jakarta: Kencana, 2017.

Sanjaya, Wina. Perencanan dan Desain Sistem Pembelajaran. Jakarta: Kencana, 2008.

Setiawan, M. Andi. Belajar dan Pembelajaran. Ponorogo: Uwais Inspirasi Indonesia, 2017.

Suprayitno, Adi. Menyusun PTK Era 4.0. Yogyakarta: Deepublish, 2020.

The King Eduka. Modul Ringkasan SBMPTN TKPA. Jakarta: CMedia, 2018.

Tim Pusat Bahasa. Kamus Besar Bahasa Indonesia. Jakarta: Pusat Bahasa, 2008. 